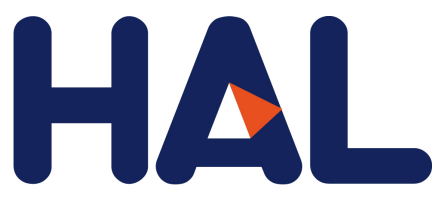

archives-ouvertes

\title{
How is climatic adaptation taken into account by legal tools? Introduction of water and vegetation by French town planning documents
}

\author{
M.L. Lambert-Habib, J. Hidalgo, C. Fedele, A. Lemonsu, C. Bernard
}

\section{- To cite this version:}

M.L. Lambert-Habib, J. Hidalgo, C. Fedele, A. Lemonsu, C. Bernard. How is climatic adaptation taken into account by legal tools? Introduction of water and vegetation by French town planning documents. Urban Climate, Elsevier, 2013, 4, pp.16-34. 10.1016/j.uclim.2013.04.004 . hal-02368966

\section{HAL Id: hal-02368966 \\ https://hal.archives-ouvertes.fr/hal-02368966}

Submitted on 18 Nov 2019

HAL is a multi-disciplinary open access archive for the deposit and dissemination of scientific research documents, whether they are published or not. The documents may come from teaching and research institutions in France or abroad, or from public or private research centers.
L'archive ouverte pluridisciplinaire $\mathbf{H A L}$, est destinée au dépôt et à la diffusion de documents scientifiques de niveau recherche, publiés ou non, émanant des établissements d'enseignement et de recherche français ou étrangers, des laboratoires publics ou privés. 


\title{
How is climatic adaptation taken into account by legal tools? Introduction of water and vegetation by French town planning documents
}

\author{
M.L. Lambert-Habib ${ }^{\text {a }}$, J. Hidalgo ${ }^{\mathrm{b}, *}$, C. Fedele ${ }^{\mathrm{a}}$, A. Lemonsu ${ }^{\mathrm{b}}$, C. Bernard ${ }^{\mathrm{a}}$ \\ ${ }^{a}$ CIRTA-CEJU EA889, Aix-Marseille Université, 2 Av. Henri Poncet, 13100 Aix-en-Provence, France \\ ${ }^{\mathrm{b}}$ GAME/CNRM, Météo-France \& CNRS, 42 Av G. Coriolis, 31057 Toulouse, CEDEX, France
}

\section{A R T I C L E I N F O}

\section{Article history:}

Received 25 July 2012

Revised 2 April 2013

Accepted 19 April 2013

Available online $\mathrm{xxxx}$

\section{Keywords:}

Urban climate

Climate change adaptation

Town planning documents

Urban heat island

Vegetation

Urban law

\begin{abstract}
A B S T R A C T
The issue of urban heat islands, UHIs, is rarely tackled in French environmental legislation and hardly ever touched in existing town planning documents. Reflection on the introduction of vegetation and water into cities is notably lacking in regularity and uniformity and local authorities may have to resort to tools from a variety of sources when working on adapting to climate change. Choices are strongly influenced by the structure of the area concerned and the characteristics of local governance. To encourage authorities and developers to take UHIs into account and integrate the creation of oases of freshness into urban planning, we try to identify the most appropriate level of operational scale, and put forward some propositions to structure the interactions between incitative documents that stimulates awareness and encourage reflection, and statutory tools that can express what is at stake in terms of actual obligations. This multidisciplinary work combines competence in urban climatology and in environment and town planning law. It takes stock of current knowledge on the subject of heat islands in French cities, analyses existing tools and suggest new paths of action to integrate the issues of adapting towns and climate in French town planning. Intentionally limited to the example of France and the technique of introducing oases of freshness (vegetation and water), the article considers several aspects of urban management. The examples given here are based on the tools set up in France but the thinking may be transposable to other legal systems.
\end{abstract}

\footnotetext{
* Corresponding author. Address: 42, a. G. Coriolis, Toulouse, France. Tel.: + 33610533795.

E-mail address: julia.hidalgo@ymail.com (J. Hidalgo).
} 


\section{Introduction}

International objectives concerning adaptation to climate change are gradually being taken in hand by national, regional and local authorities. Managing the vulnerability of urban areas to climate change has thus become a new challenge for public policies.

Since the Intergovernmental Panel on Climate Change delivered its successive reports, the strong probability that human activities are modifying the climate has been proved and accepted (Pachauri and Reisinger, 2007). The acknowledgement of this state of affairs was made concrete by the Rio Summit in 1992, ${ }^{1}$ completed by the Kyoto Protocol in 1997. ${ }^{2}$ The European Commission subsequently published a Green Paper in $2007^{3}$ proposing public actions in favour of processes mitigating climate change and also ways of adapting to it.

In France, programmes of public policies in this sense were set up in the period from 2000 to 2010. Starting from global objectives, actions were established at more and more local scales and had strong implications for regional development and town planning. The Inter-ministerial Mission on the Greenhouse Effect drew up a National Programme to contend Climate Change (Programme national de lutte contre le changement climatique, PNLCC) in 2000, followed by a National Climate Plan in 2004. In 2005 , the French energy act fixed the objective of a "factor 4 to 1 " reduction in greenhouse gas emissions by $2050 .{ }^{4}$ The two national laws in favour of the environment (known as the "Grenelle acts") adopted in 2009 and 2010 confirmed these objectives, and applied them to land planning and regional development, notably through the Territorial Climate and Energy Plans (PCETs) that have to be implemented by the French Regions, Départements and municipalities. ${ }^{5}$

Thus, local authorities at various levels face themselves with the necessity to apply these engagements for mitigating and adapting to climate change, to the development operations they carry out and to their management of urban spaces, particularly when drawing up planning documents at the various scales of their territorial competence.

In towns and cities, the effects of climate change become superimposed on the local characteristics of the urban climate that describes the changes brought to local weather conditions by the urban environment. At city scale, the urban heat island is the best known feature of urban climates (Oke et al., 1987). It can have marked consequences in terms of power demand and public health, notably during heat waves. The urban heat island also has an impact on air quality as it reinforces the effects of temperature inversion and reduces the washout by dew or mist of aerosols and certain types of pollen in the air.

This multidisciplinary article combines competence in urban climatology and urban law. It takes stock of current knowledge on the subject of heat islands of French towns, analyses existing tools and puts forward new ones for integrating the issues of adapting towns and climate in French town planning. Intentionally limited to the example of France and the technique of introducing oases of freshness (vegetation and water), the article considers aspects of urban management, excluding the question of construction techniques concerning the sole buildings.

Theoretical knowledge on urban heat islands and vegetation into towns, together with a description of the tools available in French town planning are presented with concrete examples in Section 2. Propositions on the appropriate scale of coordination and action in town planning are forwarded in Section 3 and conclusions are drawn in Section 4.

\section{Theory}

\subsection{Climate aspects}

\subsubsection{Theoretical basis of urban heat islands (UHI). The urban climate of French towns}

The term "urban microclimate" refers to the climate conditions of an urban area that differ from those of the surrounding countryside and can be attributed to urban development. The main charac-

\footnotetext{
1 http://www.un.org/documents/ga/conf151/aconf15126-1annex1.htm/. [En ligne].

2 http://unfccc.int/resource/docs/convkp/kpeng.pdf. [En ligne].

${ }^{3}$ http://eur-lex.europa.eu/LexUriServ/site/en/com/2007/com2007_0354en01.pdf. [En ligne].

${ }^{4}$ http://www2.ademe.fr/servlet/KBaseShow? sort=-1\&cid=96\&m=3\&catid=17567. [En ligne].

5 http://www.pcet-ademe.fr/. [En ligne].
} 
teristic of an urban heat island (UHI) is a temperature rise localised in the town centre relative to the less built-up surroundings. The UHI is generated by the heat emitted by human activities (traffic, industry, heating/air conditioning, etc.) and also by the reduction in evapotranspiration caused by the ground made impermeable, the trapping of direct and reflected solar radiation in the streets, heat storage in materials, and a reduction of ventilation in the streets because of the presence of buildings.

In the countryside, most of the solar energy is used by plants in the evapotranspiration process, whereby they extract water from the soil through their roots and evaporate it into the atmosphere. A great part of the remaining solar energy heats the air. Country air is usually hotter in the day than at night. Vegetation and the ground heat up only a little. In contrast, in towns, the solar energy obviously warms the air but, above all, heats up the impermeable surfaces and the buildings, which store large amounts of energy. At night, the presence of hotter urban surfaces limits the cooling of the surrounding air. It is the time-shift between daytime heating and night-time cooling in rural and urban areas that is the source of the UHI.

The UHI shows cycles in time and space: at mid latitudes it is characterised by a daily cycle having its maximum intensity at night, a minimum of intensity generally before dawn, which may reach negative values (the town centre being colder than the environs) during the day, and a slow increase from sunrise onwards. Seasonal cycles also affect its frequency and intensity. Anticyclonic weather conditions with a lot of sunshine favour its formation, and rain, clouds and wind have the opposite effect.

Spatially, the UHI has a horizontal structure characterised, particularly at night, by a sharp increase in temperature at the boundary between the rural surroundings and the built up area, and a region where the temperature increases gradually towards the town centre. The temperature reaches its maximum value in the central areas with the highest building density. The horizontal temperature distribution can show irregularities connected with topographical variability and differences in land use. In the vertical direction, the nocturnal UHI generally extends for a few hundred metres above the ground (between 150 and $300 \mathrm{~m}$ of altitude). During very sunny days with little wind, the height may reach 2000-2200 m (Arnfield, 2003).

In France, studies of the thermal aspects of the urban microclimate have been principally centred around the intensity and the horizontal and vertical extent of the UHI. Such studies have mainly been based on observations made during specific measuring campaigns in the cities of Paris (Menut et al., 2000), Marseille (Cros et al., 2004; Mestayer and et al., 2005), Strasbourg (Najjar et al., 2004), Toulouse (Masson et al., 2008) and Nantes (Mesteyer et al., 2011). In Toulouse, for example, intensities of 7-8 ${ }^{\circ} \mathrm{C}$ were observed during summer nights and $1-2{ }^{\circ} \mathrm{C}$ in the daytime (Hidalgo et al., 2008). For Marseille, lower intensities were recorded because of the influence of the sea and the topography, which were superimposed on the urban effects (Pigeon et al., 2006).

Data provided by local weather observation networks are also much used. A sufficiently dense network of observation masts, like that of Paris, enables mean temperatures to be studied according to the distance from the city centre and can bring out relationships between wind direction, the intensity of the UHI and "deformations" of the heat island at the end of the night (Cantat, 2004). For 1999, the mean intensity of the Paris UHI was found to be $3.1^{\circ} \mathrm{C}$ with maxima of $7.8^{\circ} \mathrm{C}$ in August and September. During the 2003 heat wave, the nocturnal heat island in Paris - over an average of 15 consecutive nights - was $4{ }^{\circ} \mathrm{C} .{ }^{6}$ The intensity of the UHI can vary with the type of weather, between $10{ }^{\circ} \mathrm{C}$ with clear, calm weather and $2.3^{\circ} \mathrm{C}$ with overcast skies and wind (Cantat, 2004). For Strasbourg, early in nights with clear skies, UHIs of $7.5^{\circ} \mathrm{C}$ have been observed (Ficher, 2009). Strasbourg city centre seems to be more affected by heat waves than the surrounding rural area (Matzarakis et al., 2003).

Numerical modelling studies with atmospheric models have also been made for Paris, Marseille and Toulouse among other places. Modelled summer UHIs are as high as $10^{\circ} \mathrm{C}$ for Paris (Lemonsu and Masson, 2002), do not exceed $3{ }^{\circ} \mathrm{C}$ for Marseille (Lemonsu et al., 2004), and reach $6{ }^{\circ} \mathrm{C}$ for Toulouse, extending to a height of $2200 \mathrm{~m}$ over the city (Hidalgo et al., 2008). These modelling studies have refined the description of the interactions between the UHI and the sea breeze for Marseille and the generation of urban breezes for Paris and Toulouse.

For the city of Lyon, an UHI study was carried out for the Town Planning Agency using satellite images. It was found that the urban fabric occupied $50 \%$ of the surfaces at $25{ }^{\circ} \mathrm{C}$ and that half the pop-

${ }^{6} \mathrm{http}: / /$ climascope.meteo.fr/. [En ligne]. 
Table 1

Probability of having a maximum temperature higher than $35{ }^{\circ} \mathrm{C}$ in summer for the present climate and the $\mathrm{A} 2$ emission scenario (adapted from the IMFREX project http://imfrex.mediasfrance.org/).

\begin{tabular}{|c|c|c|c|c|c|c|c|c|}
\hline & Lille & Rennes & Paris & Strasbourg & Lyon & Bordeaux & Toulouse & Marseille \\
\hline Present & 0.01 & 0.01 & 0.01 & 0.01 & 0.02 & 0.02 & 0.02 & 0.01 \\
\hline Projected & 0.05 & 0.09 & 0.11 & 0.13 & 0.22 & 0.12 & 0.24 & 0.27 \\
\hline
\end{tabular}

ulation of the built-up area lived in sectors where the temperature was higher than $25{ }^{\circ} \mathrm{C}$ (the reference temperature for July). In Lyon, 580000 people lived in sectors where the reference temperatures were above $26^{\circ} \mathrm{C}, 325000$ in sectors where the reference temperatures were above $27^{\circ} \mathrm{C}$ and 11000 people were subjected to extreme reference temperatures, higher than $30^{\circ} \mathrm{C}$ (Lyonnaise, 2010). Other cities have also been studied, e.g. the metropolitan area of Lille (Charabi et al., 2002; Bigot et al., 1950) and Nantes (Benzerzour et al., 2011).

\subsubsection{Potential impacts of climate change in France. Thermal aspects}

Work on the impacts of climate change for France as a whole has been conducted either on the basis of observations (Moisselin et al., 2002; Dubuisson and Moisselin, 2006) or by using climate projections (Déqué et al., 2005, 2007; Martin et al., 2005; Boé et al., 2006; Planton et al., 2008; Lemonsu et al., 2012) forced by emission scenarios produced by the IPCC in 1992 (Nakicenovic et al., 2000). The studies show a rise in mean temperatures in France during the 20th century that is noticeably more marked than the rise established by the IPCC at planetary level (Moisselin et al., 2002). The projections suggest that, whatever the emission scenario considered, it is highly likely that summer heat waves in France will be more frequent, of longer duration and more intense that in the present climate. It is also probable that intense precipitation will increase in winter and that, above all, periods of drought will be longer in summer. According to emission scenario B2, the mean temperature in France is expected to increase by $2-2.5^{\circ} \mathrm{C}$ between the late 20 th and the late 21 st centuries, and precipitation should increase slightly in winter and decrease more strongly in summer (by 5-25\%). According to emission scenario A2, climate change would be much more marked, with greater warming $\left(3-3.5^{\circ} \mathrm{C}\right.$ ), dryer summers (by $20-35 \%$ ) and an amplification of extreme events. In particular, towards the end of the century (2070-99) one summer in two would be at least as hot as the summer of 2003 (Déqué et al., 2007; Planton et al., 2008). ${ }^{7}$

The impact will not be uniform over the whole country. Table 1 shows the probability of the daily maximum temperature exceeding the threshold of $35^{\circ}$ for 8 French cities, considering the present climate and the climate forecast by the models for the end of the 21st century. The southern and southeastern regions, in particular Toulouse and Marseille, would be the most vulnerable.

\subsubsection{Reinforcement of the UHI by climate change}

The temperature rise connected with climate change and the increased frequency of extreme climate phenomena are likely to aggravate the thermal features of the urban environment, such as the UHI, in the coming decades or to extend the urban areas concerned (Jones et al., 1990; Wilby, 2003; Rosenzweig et al., 2005; Gaffin et al., 2008; Fujibe, 2010).

The consequences at city scale will be numerous and are far from simple to assess. A temperature increase will probably prove beneficial in winter by improving the comfort of the outdoor climate and reducing the power demand for heating. In contrast, it may well be harmful during heat waves, with consequences for the thermal comfort of the citizens and for air quality. It would thus have an impact on health and also on power requirements through the demand for air conditioning.

During the summer of 2003, a strong heat wave over Europe led to the loss of more than 70000 lives, many of them in French urban populations (Evin and d'Aubert, 2004). The event was marked by very high temperatures during the nights, aggravated by the urban heat island effect in cities. The consequence of this was that people's bodies were not restored at night and the effects were serious for the most fragile individuals (Bretin et al., 2003; Laaidi et al., 2012).

\footnotetext{
${ }^{7}$ Déqué, M. http://imfrex.mediasfrance.org/web/. IMFREX project. [En ligne].
} 
Various interdisciplinary research groups in France are currently working to evaluate the interactions among urban development processes, the urban microclimate, and climate change. Three national research actions, funded by PIRVE (interdisciplinary research programme on towns and the environment) are particularly noteworthy: the study of interactions among city layout, lifestyles and urban climate in the outskirts of Toulouse (Houes-Jouve, 2008); the study of the vulnerability of the coastal systems of Marseille (Lambert-Habib, 2011) and of vulnerability and resilience to climate changes in urban settings (Quenault, 2008).

A variety of studies have been performed or are in progress concerning Paris: EPICEA (Lemonsu et al., 2012), LE GRAND PARI for Paris and its suburbs (Masson et al., 2012), VURCA (Beaulant et al., 2012) and MUSCADE, ${ }^{8}$ their aim being to study the impact of climate change at the scale of the Paris urban area, notably in terms of thermal stress during heat waves and power requirements. For the Toulouse area, the ACCLIMAT project ${ }^{9}$ has the objective of studying the interactions among the processes of urban development, urban microclimate and climate change by means of a numerical modelling platform bringing together numerical models from different disciplines: meteorology (Meso-NH Lafore et al., 1998), socio-economics (NEDUM Viguié et al., 2012), geography (SLEUTH Clarke et al., 1997) and architecture (GENIUS).

\subsection{A climate adaptation technique: oases of freshness}

Some scientific and technical recommendations would enable the impact of rising temperatures on urban areas to be attenuated. They fall into two categories. The first concern the changes that need to be made to human activities (development of public transport, efficient use of energy). The second concern techniques for cooling the town, based on natural ventilation (use of winds connected with the morphological and geographical characteristics of the town) and how the surface of the town is covered (with two pathways: changing the albedo by acting on the external materials used for construction or renovation, and introducing vegetation and water bodies).

\subsubsection{The climatic role of vegetation and water in towns}

Vegetation affects the aerodynamic, radiative, hydric and thermal properties of the urban environment. It is often put forward as an effective means to limit the intensity of the UHI and the bioclimatic discomfort of city dwellers. In terms of physical mechanisms, two major effects are to be considered:

Firstly, green spaces humidify the city atmosphere locally, creating an oasis effect (Oke et al., 1987). During the day, evaporation from natural soil and evapotranspiration by plants limit the warming of the ambient air and the storage of heat in infrastructure. Thus the energy potentially available for reducing night-time cooling - the principal mechanism leading to the summer heat island - is reduced.

Secondly, the presence of trees also has a major effect on the daytime radiation budget. Plant cover intercepts the incident solar radiation, providing shade that limits surface heating (Oke, 1989). It also modifies the airflow near the surface.

At a very local scale, the shade provided by trees tends to reduce the temperature of the air under the plant canopy (Souch and Souch, 1993; Shashua-Bar and Hoffman, 2000). Trees in the streets can thus considerably improve the comfort of pedestrians while also reducing the energy required for air conditioning in the nearby buildings (Thayer and Maeda, 1985; Ca et al., 1998). Recently, more and more green roofs and living walls have been making their appearance, essentially as a way of improving the thermal and energy behaviour of buildings. By absorbing the incident solar radiation for its growth and biological functions, vegetation acts as a sun screen (Eumorfopoulou and Kontoleon, 2009; Onmura et al., 2001; Takebayashi and Moriyama, 2007). It also limits seasonal temperature variations and can have a certain energy saving effect - without, however, attaining the efficiency of a layer of insulating material (Eumorfopoulou and Kontoleon, 2009; Eumorfopoulou and Aravantinos, 1998).

At a larger scale, numerous measurement campaigns have pointed out the oasis effect of city parks by recording cooler air temperatures in the parks than in the surrounding districts or the rest of the

\footnotetext{
${ }^{8}$ MUSCADE project, 2010-2012. http://www.cnrm.meteo.fr/MUSCADE. [En ligne].

9 Project, 2010-2013 ACCLIMAT. http://www.cnrm.meteo.fr/ACCLIMAT. [En ligne].
} 
city (Ca et al., 1998; Jauregui, 1991; Eliasson, 1996; Spronken-Smith and Oke, 1998; Potchter et al., 2006). The temperature difference between the park and the city is often greatest in the afternoon or evening. Differences can reach $3-4{ }^{\circ} \mathrm{C}$ but are very variable and depend on a number of factors. Several studies, e.g. (Barradas, 1991) have shown that the size of the park influences the cooling effect. A review by Bowler and co-authors (Bowler et al., 2010) indicates that, when they cover more than 3 ha, urban parks are systematically cooler than the rest of the city but this is not necessarily the case for smaller parks. The type of vegetation also plays a major part and cooling is often more marked in parks with many trees (Potchter et al., 2006). Finally, Shashua-Bar and Hoffman (Shashua-Bar and Hoffman, 2000) have shown that the oasis effect varies according to local climatic conditions. Their measurements reveal more noticeable cooling on hot days.

The greening of cities thus seems to be a pertinent strategy for mitigating urban effects and adapting to climate change. Urban parks have an important influence on town planning, particularly since the cooling they induce can extend beyond their geographical limits and affect the heat island of the city as a whole. Several measurement campaigns have indicated that the spatial area influenced by parks depends on their size: the effect can be measured up to $1 \mathrm{~km}$ away for small parks of 35 ha (Ca et al., 1998) and at a distance of more than $2 \mathrm{~km}$ for large parks of 500 ha (Jauregui, 1991).

Recently, modelling studies have looked into the impact of various development strategies on the urban climate, and greening strategies in particular. In the consultation concerning the Grand Pari(s) project, the Descartes group (Groupe Descartes 2009 (Masson et al., 2012) drew up a strategy for the Paris area that combined replacing cereal farming by market gardening, extending the forested areas, developing lakes and using reflecting paint in the suburban areas. A numerical simulation using this scenario with the extended heat wave of 2003 showed a significant attenuation of $2-3{ }^{\circ} \mathrm{C}$ of the Paris urban heat island without changes being made to the city itself but only to its outskirts (Fig. 1). A study conducted on Toronto using a similar method (Krayenhoff et al., 2003) demonstrated a reduction of $1-2{ }^{\circ} \mathrm{C}$ in the urban heat island through the use of irrigated green roofs.

The presence of water is an effective air conditioning device on local scales and has a quantifiable effect at distances of up to about 50 metres (de chaleur, 2008). Its cooling potential varies according to the wind speed, the area covered by the water body and the topography of the area (open spaces). The effect is more noticeable when the air is dry. In the case of the climate of Seville, cooling by evaporation lowered the peak temperature by about $7{ }^{\circ} \mathrm{C}$ (PACA). As evaporation is proportional to the area of contact between the air and the water, processes creating small drops, such as sprays and vaporizers have sometimes been preferred. The efficiency of evaporation obtained is higher than with natural evaporation but far more water has to be used - and water is a resource that must not be used indiscriminately. Initiatives exploiting rainwater are thus starting to be implemented.

Regulations concerning water management came into force in France in 1992. The principle is to avoid aggravating run-off relative to the natural situation. This imposes management and conservation procedures for rainwater, such as storage, infiltration and the creation of wetlands. The idea is to slow the passage of water in order to favour its evaporation and increase the hydraulic absorption capacity. This also limits water pollution by run-off and avoids the saturation of networks during heavy storms that can cause flooding in urban areas.

\subsubsection{Non-climatic aspects of oases of freshness in the city}

Finally, when we consider the question of town planning to mitigate and adapt to climate change, it is important to make a full and objective evaluation of the scenarios, in other words to take all the induced effects into account and consider their possible interactions (e.g., microclimate, air quality, noise, atmosphere...) without forgetting the costs associated with the implementation and maintenance of the chosen strategies. Using motor mowers and leaf blowers involves noise pollution. Phytosanitary products (pesticides and fertilisers) and certain animal or plant species can be sources of pollution, mainly having harmful effects on people's health through allergies and the introduction of viruses and pathologies.

Although urban vegetation can make the city climate less severe, it can sometimes have negative effects, more rarely mentioned in the literature. Thayer and Maeda (Thayer and Maeda, 1985), whose work points out the beneficial effect of street trees on the summer climate, also stress that, in winter and at some latitudes, these trees can cast so much shadow on the walls of buildings that more 
(A1)

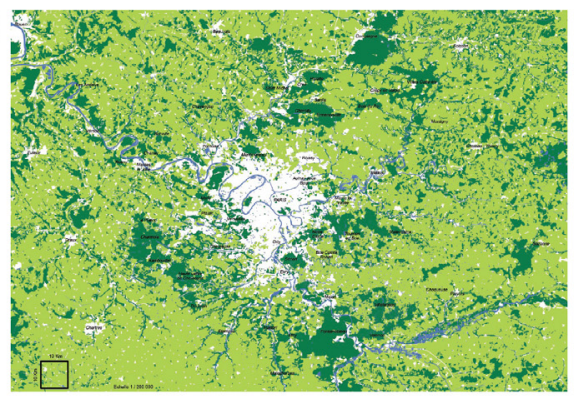

(A2)

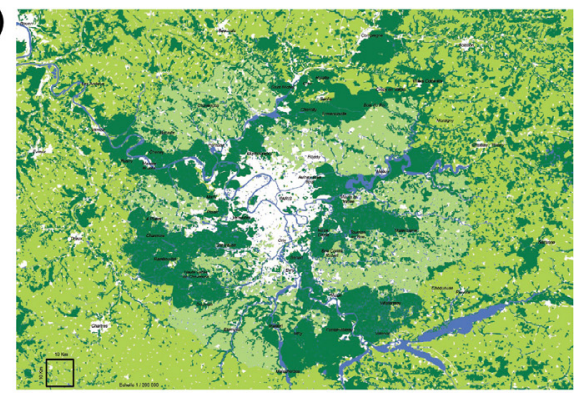

(B)

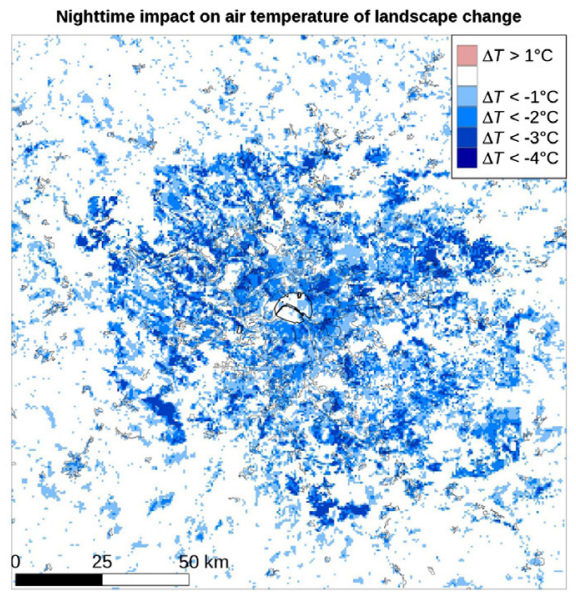

Fig. 1. Vegetated surfaces and water masses for Paris, France, for present situation (A1) and future 2030 scenario (A2). Modelled difference in $2 \mathrm{~m}$ air temperature between both scenarios (B) (Figure adapted from Masson et al. (2012)).

heating is needed inside them. Tall plants can also affect the airflow. In this context, Potcher et al. Potchter et al. (2006) have shown through experiments that some wooded parks generate uncomfortable bioclimatic conditions at night, in connection with a local increase in the humidity of the air and a reduction of the airflow by the trees. This impact on ventilation can also cause local deterioration of the air quality, notably by trapping pollutants in streets where the traffic is heavy (Maiheu et al., 2010; Buccolieri et al., 2010).

The main issue concerning greening strategies is the question of the water resources needed to maintain the plants and how effective the vegetation actually is. Onmura et al. Onmura et al. (2001) and Krayenhoff et al. Krayenhoff et al. (2003) have clearly shown that the cooling effect of green roofs is greater when they are irrigated. Yet very few works have tackled this problem and evaluated the water consumption of urban vegetation. One noteworthy study in a semi-arid climate is that of Shashua-Bar et al. Shashua-Bar et al. (2009), who tested various landscaping strategies in two semiclosed courtyards and assessed the efficiency of these layouts using a balance between the effective cooling of the air in the courtyard and the amount of water needed to maintain the system. According to this study, trees provide the most effective cooling while lawns consume very large quantities of water.

In addition, the constraints associated with the urban environment, such as contact with large numbers of people, weaken the plants' equilibrium and make it difficult for the planted environments to survive independently, without specific work to correct, repair and accompany them.

It is important to avoid an impression of suffocation due to the presence of too much greenery, a large number of trees lined up, or a humid atmosphere. The spaces should give a feeling of fresh air. The quality of how the urban atmosphere is felt is being increasingly taken into consideration in French planning and research projects. This is the case for the EUREQUA (2012-2014) research project, 
the aim of which is to define a methodology for evaluating the quality of the environment on the scale of a district for the cities of Paris, Marseille and Toulouse.

Planning, by defining zones with determined destinations and uses, can also be a source of conflict. Local authorities that envisage the introduction of oases of freshness are confronted with the problem of the scarcity and price of land. When following the principle of urban renewal, the ideal is to convert wasteland and land that has fallen into disuse (transformation of old railway tracks into green corridors, for example). Integrating "nature spaces" into cities also leads to inequality in terms of both comfort and the market value of buildings since the presence of parks and gardens brings attractiveness and dynamism to an area, thus encouraging increases in house prices. The town of Breda, in the Netherlands, used this principle to lower the burden of local authority expenditure by taxing developers when green spaces or water bodies added value to the dwellings built nearby (Masboungi et al., 2008). This resource was then allocated to the upkeep of municipal parks and open spaces - a pertinent and interesting idea that could be taken up in France.

The next section presents the French town planning tools and various examples of how they are used to incorporate oases of freshness.

\subsection{French town planning tools}

In France, urban planning has gradually been enriched with documents or plans specific to environmental issues. Some of these tools are binding regulations, others are only encouragements, although they can invite local authorities to deal with the question of the urban climate .

\subsubsection{Traditional town planning regulations}

French town planning is built on two levels, corresponding with two types of plans. At the intercommunal scale, the Territorial Coherence Scheme (SCoT) is supported by a structure including several towns or villages. It is a strategy document, set up in 2000 , that enables the municipalities of the area, upstream of local town planning, to think about important issues of urbanism, housing and sustainable development of the intercommunity territory. The more precise planning of choices concerning urban development is implemented by the Local Development Agency (Agence Locale d'Urbanisme) or by the services of the city, at municipality or intermunicipality scale, through the Local Urban Development Plan (Plan Local d'Urbanisme - PLU).

The SCoT is composed of a presentation report, a project for land use and sustainable development (PADD), and an orientation and objectives document (DOO). Its orientations notably have to respect the principles of balance between urban development and the conservation of agricultural and natural spaces, the reduction of GHG emissions and the protection of the quality of natural elements, including ecological continuities. ${ }^{10}$ The SCoT can also follow an aim of urban density by fixing, in certain geographical sectors, a minimum building density which will be imposed in the PLU. ${ }^{11,12}$

In the SCOT, references to the issues about adaptation to urban warming are limited. One reason for this is that the climate is not mentioned as such in the informations expected of the diagnostic survey of the presentation report. ${ }^{13,14}$ In addition, the institutional structure leading the SCoT does not always have the engineering and financial resources necessary for the studies and evaluation.

Considered as new, the question of adapting cities to climate change and UHIs is today only included in the deliberations of the cities that have advanced the furthest on this theme. When it does appear, it tends to be integrated in the tools fixing the regulations of land-use at town or city scale, i.e. the PLU.

The PLU: The PLU is a central town planning document since its provisions are legally opposable to all requests concerning land-use (building permits, subdivision permits, etc.). It includes a presenta-

\footnotetext{
10 Code de l'Urbanisme art. L. 121-1.

11 Code de l' urbanisme., art. L. 122-1-5 VIII.

12 Code de l' urbanisme., art. L. 122-1-5 III.

13 "The SCOT sets out the diagnosis established concerning economic and demographic forecasts and the needs detected in the domains of economic development, agriculture, use of space, environment, social balance in housing, transport, equipment and services".

${ }^{14}$ Code de l'urbanisme art. L. 122-1.
} 
tion report, a PADD, a set of regulations, graphical documents and appendices. The PLU regulations precisely define the land-use rights that are binding. They must be compatible with the objectives fixed by the PADD. The objectives assigned to the PLU also lay emphasis on saving space by raising building density). ${ }^{15,16}$

The subject of UHIs sometimes appears incidentally or indirectly in some of the PLUs adopted. After deliberation, Lyon, Grenoble and Saint-Étienne decided to favour trees as an adaptation tool and to recommend storing rainwater in porous road surfaces with reservoirs (European Amica Project).

A PLU may be completed by manuals of recommendations containing precise provisions in favour of continuous green corridors or introducing vegetation for comfort in summer. These manuals, appended to the document, may have a variety of titles, such as "range of vegetation", "conservation measures prescribed along streams and torrents", or "manual of environmental recommendations". The difficulty, however, lies in determining how legally binding these manuals should be. Requirements set legal standards that have effects towards third parties, whereas recommendations provide advice for petitioners without having any legal force.

\subsubsection{Environmental planning tools having incentive effects}

In addition to the statutory town planning, local authorities develop environmental policies on their territory, which may take the form of a variety of tools: Environment Charters, local Agendas 21 and, more recently, Territorial Climate and Energy Plans (PCET). These are generally not binding but can be incentive and provide a basis for reflection .

Environment Charters, developed since 1992 (Ministerial circular of 11 May 1994), allow engagements to be taken among elected representatives, technicians and the population, in the form of recommendations founded on an environmental survey of the territory and the setting up, monitoring and assessment of development projects.

They can also serve as preparatory studies before town planning documents are drawn up, providing objectives and recommendations to be included in the final document. To go further, it is possible to make them binding by including them in contractual documents concerning the development operations.

Although such undertakings often remain fairly general, some charters deal with more precisely defined subjects, like "ecological adapted management charters" or "tree charters". The latter may be closely connected with the creation of oases of freshness as they include undertakings affecting the design and management of green spaces (collecting rain to water the plants, for example) and can also contain explanations on the effects of vegetation on local climate or the UHI phenomenon. They may be accompanied by plans called "green plan" or "vegetation plan", which serve as reference documents for the administrative departments responsible for the territory, even though they do not have the official status of regulations.

Local Agendas 21 are programming procedures that seem to be stronger than the Charters and can lead to plans of action and projects which, although they are not compulsory, can nevertheless constitute a tool for coordinating local adaptation strategies. Drawn up after a diagnostic survey of the territory, the Agenda 21 contains a continuous assessment and improvement strategy that names "combating climate change" among its five aims and promotes "strategies for adapting to the foreseeable changes in climate in the various domains impacted". It could thus concern adaptation to urban warming.

The Territorial Climate and Energy Plan (PCET), constitutes the specific tool for the local climate strategy and is the local expression of the national Climate Plan. It is compulsory for all local communities with populations of more than 50000 to draw up such a plan by December 2012. Established at different territorial levels, from regions to major towns, it aims to develop in the territory concerned a dual strategy to mitigate and adapt to climate change. This objective can be included in all public policies (town planning and development, transport, energy, waste management, agriculture...). However, the content of its recommendations will probably be rather vague because of the very global approach applied to the set of problems.

\footnotetext{
15 Code de l' urbanisme art. L. $123-1-5,13^{\circ}$ bis.

16 Code de l' urbanisme art. L. 128-1.
} 
A study of the PCETs already drawn up reveals that their main objective is limited to mitigate climate change by aiming to reduce greenhouse gas emissions. Most of the actions planned concern evaluation of emissions level and its evolution within the territory, strategies for reducing emissions and devices to monitor, assess and continuously improve them. Consequently, even though the principle of adaptation is generally a theoretical aim, it does not appear in the concrete actions.

Certain municipalities or inter-municipalities are nevertheless starting to include the question of UHIs in their PCETs, but without necessarily mentioning the term. Thus the Paris PCET contains plans for a large vegetation programme for the capital, to fight against "the microclimates engendered by the density of the city". ${ }^{17}$ The Lyon urban area, in parallel with integrating the "Tree mission", into its Climate plan, has fixed itself the objective of mapping all the UHIs in order to better adjust the actions of the PCET (Lyonnaise, 2010). This document will serve to "produce a cool net between the shady pedestrian walkways already in place and the identified urban heat islands". "We will thus be able to structure our policies around these islands and halt the population exodus towards the outskirts of the city, which is responsible for increased travelling" (Crépeaux et al., 2009).

Another example is given by the PCET of the Grenoble metropolitan area. Temperature measurements have been made that show up the presence of UHIs. With the help of AURG (the urban planning agency of the Grenoble region), ${ }^{18}$ a programme to work on vegetalizing the area has been set up with a network of people responsible for the green spaces in the municipalities. The solutions advocated aim to reduce the areas of impermeable surfaces, plant vegetation, reinforce the presence of water in the town centres, and choose materials and colours that limit the absorption of solar radiation.The green and blue corridors (TVB) is a new tool for maintaining the ecological continuities introduced by the French "Grenelle 2" act. ${ }^{19}$ The initial aim is to stop the loss of biodiversity by correcting the effects of anthropic segmentation of natural habitats, and by participating in the conservation, management and restoration of the environments necessary to ecological continuity, be they land (green corridor) or water (blue corridor) environments.

The TVB relies on three levels of intervention: national, regional and local. National orientations indicate the framework chosen for the protection of ecological continuities, which is then detailed by regional ecological coherence schemes. These schemes, drawn up jointly by the region and the state, present the regional scope of the ecological continuities and state the contractual measures set up.

The practical consequences of the scheme are limited as it only has to be brought to the notice of the municipalities or the state establishments that are competent in urban planning matters. But failure to respect this information will have no incidence on the procedure for establishing urban planning documents. The TVB system does not introduce any new zoning indexes to be added to the traditional land-use zoning: urbanised areas, agricultural, natural or forest areas. That said, the objective of "conservation, restoration and creation of ecological continuities" which is now imposed in town planning documents, should incite their authors to preserve the green corridors. Subsequently, thinking on the planting of green corridors within the fabric of cities could join the creation of oases of freshness with the concrete objective of decreasing the intensity of urban heat islands, before any definite work in this direction is yet undertaken in French cities.

Nevertheless, a few examples of "green and blue metropolitan areas" are already appearing, such as Nantes, where interesting work has taken place on wetlands, continuous pedestrian walkways, adapted management of public green spaces and the creation of urban forests. The presentation of the Plan "restoring and valorizing nature in the city" (Grenelle engagement $n^{\circ} 76$ ) and, above all, the Urban Green Corridors research programme, ${ }^{20}$ which aim is to validate the effects of green

\footnotetext{
$\overline{17}$ www.iau-idf.fr/fileadmin/Etudes/etude_761/les_ilots_de_chaleur_urbains_Adaptation_de_la_ville_aux_chaleurs_urbaines.pdf pages 43 and 44 "l'action par le végétal", October 2010. [En ligne].

18 http://www.lametro.fr/431-plan-climat-grenoble.htm. [En ligne].

19 Code de l'environnement, new art. L. 371-1.

20 Research programme funded by the French national research agency (ANR): Assessment of urban green frames and development of a referential: Assessment of urban green networks and setting up of frames of reference: infrastructure between aesthetics and ecology for a new urbanity, of which task $n^{\circ} 6$ is "assessment of ecosystem services rendered by forms of urban vegetation with respect to pollution". http://www.trameverteurbaine.com.
} 
infrastructures to attenuate pollution and temperature rise, give hope for progress in this sense so as to adapt to urban warming.

\subsubsection{The experience of eco-districts}

In France, the problem of adapting to urban warming has been tackled at the scale of a quarter or a building program by means of "Eco-district" or "sustainable district" approaches. By considering ambient comfort, the planting of vegetation in public spaces and the use of natural materials, it is possible to limit UHI phenomena. We will look at two eco-districts here, although many initiatives have been developed in recent years.

The question of urban warming was clearly taken into account in the Masséna-Bruneseau district, ${ }^{21}$ a part of the "Paris Rive Gauche" operation. Various scenarios for reducing the temperature by $2{ }^{\circ} \mathrm{C}$ by 2020 were studied. The temperature and humidity of the air were analysed to measure the potential for cooling by working on water and vegetation, then ideas like water vaporisation and screens of vegetation were studied, and finally the installation sunken gardens and the use of certain species of plants were examined.

The example of the eco-district of the ZAC of Pielles in Frontignan seems to be one of the most interesting because of the in-depth reflection it involved on thermal comfort in summer in a Mediterranean climate (PUCA, 2009). The project was oriented towards finding technical solutions for optimising the form of the urban area by taking the features of the Mediterranean climate into account (summer heat and dominant winds). Corrective plant elements were integrated in the heart of the islands: the angles of buildings had to use porous elements or dense plantations so as to attenuate the warming effects or correct the air turbulence. Also, ecological continuities with the lagoons were preserved and enriched, giving breathing spaces in response to the high density of the operation. The infiltration and natural filtration of rainwater were favoured by broad vegetated ditches and green roofs.

In conclusion, it is noteworthy that, at operational scale, more and more importance is being attached to natural spaces. Yet, these efforts are made without any aim being expressed, or with goals other than adapting to the UHI problem, such as protecting biodiversity and the quality of life, i.e. without the heat island effect being studied. Consequently, the contribution of these developments to summer comfort are only incidental.

The Environmental Approach to Urban Planning (AEU), proposed by ADEME (the French Environment and Energy Agency) is a tool to help decision makers and accompany projects. Its aim is to consider environmental issues as fundamental elements of town planning choices. This method is intended to help project managers, prime contractors and urban professionals in their projects, whether they concern town planning documents (SCoT and PLU) or development operations (areas of combined development (in French, Zones d'Aménagement Concerté $\left(\mathrm{ZAC}^{22}\right.$ ), estates, urban redevelopment operations). The AEU has no statutory value and corresponds to a certification approach, with a registered trademark. The subjects covered concern, among others, biological diversity, water management and the climatic environment, and can thus promote the creation of oases of freshness.

\section{Results and discussion on the coordination and scale of action to promote the introduction of vegetation and water masses}

The issue of UHIs is rarely tackled in environmental planning documents, however, and hardly ever touched on in existing town planning documents. Reflection on the introduction of vegetation and water into cities is notably lacking in regularity and uniformity, and local authorities resort to one or more tools to work on adapting to climate change. Choices are strongly influenced by the structure of the area concerned and the characteristics of local governance.

\footnotetext{
21 www.parisrivegauche.com. [En ligne].

${ }^{22}$ A ZAC is a "zone within which a public community or establishment having the authority to do so decides to intervene to develop and equip plots of land or have such plots developed and equipped [...] with a view to subsequently transferring them [...] to public or private users".
} 
To encourage the consideration of UHIs and integration of oases of freshness into urban planning, it is necessary to identify the most appropriate level of the operational scale of intervention and to examine the interactions between incitative documents that simply stimulate awareness, and the binding regulations that can express actual obligations. The examples given here are based on the tools set up in France but the way of thinking may be transposable to other legal systems.

\subsection{Pertinence of reflection and incentives on a broader scale}

In planning and development, the benefits of an enlarged territory are currently praised as being at "the right scale" for sustainable development. New levels of action are appearing following the examples of "Grand Paris" or the areas of coordinated development around a metropolis (Geneva) (Masboungi et al., 2010).

The level of proximity decision is itself evolving in France towards a reinforcement of inter-communality and the creation of "metropolises" in urban areas. In parallel, in the "Grenelle 2" act, living areas known as "bassins de vie" and inter-communalities with populations of more than 100000150000 are deemed to be pertinently sized for the introduction of adaptation to climate change and efficient use of energy in the planning and development objectives. Others look to even bigger areas, e.g. for management of the Paris metropolitan area at regional scale.

Several reasons have been brought forward for the advantages of these "inter-territorial" policies.

Among them is a greater ability to take account of the diversity and inequality of the territories (social and cultural dimensions), and the interactions between the reference territory and the spaces it is in relation with.

But the current dynamics of "enlarging the scale" of action seems to go against the need for finerscale studies appropriate for adapting to the microclimatic realities specific to the urban environment. Nevertheless, the two scales should not be perceived as incompatible, and the larger-scale tools (such as the SCoT) can enable people to think about UHIs and propose paths of action that will become operational at the lower scale (PLU of the town or district regulation). The scale-broadening reflection should not cause difficulties in the execution of local initiatives better suited to climate change adaptation actions.

\subsubsection{The PCET: a broad scale of analysis with interesting potential}

The PCET, a tool specifically dedicated to climate questions linked to a territory, appears to be the "natural" tool for considering the problem of urban warming in France today. The development of green spaces can deal with two aims of the plan: in terms of mitigation of climate change, it helps to maintain "carbon sinks" and, in terms of adaptation to climate change, plants are temperature moderators that act on summer comfort. Although current PCETs sometimes make reference to indoor summer comfort, through actions on buildings intended to reduce the need to resort to air conditioning, it will be necessary, from now on, to broaden these considerations to outdoor summer comfort by including actions to combat UHIs. Such actions could also indirectly improve indoor comfort and reduce the need for air conditioning.

The interaction with urban planning documents is relatively flexible insofar as the SCoTs and PLUs are obliged to take PCETs into consideration only when they exist. ${ }^{23}$ But even though they are not obligatory, they can form an efficient means of information, encouragement and incentive for local initiatives since they address the territory's institutions, public policies, and local players. In addition, the PCET approach includes obligations for follow-up and evaluation, which are interesting exercises for improving the amenities made (verification of the effectiveness of the oases of freshness created, for example).

\subsubsection{Possible interaction with green and blue corridor}

As we have seen, green and blue corridors can contribute to adaptation to urban heating, even if this is not their principal aim. Although, scientifically speaking, the ecological efficiency of a green

\footnotetext{
${ }^{23}$ Code de l'urbanisme art. L111-1-1.
} 
corridor is based on different scales of reflection (large transregional continuities to small, very localised continuities), the regional scale remains the priority and, for the moment, the local scale seems to be relegated to second place. Thus, how the TVB fits into the SCoT is globally more studied than the integration of biological corridors in the PLU. And yet, "although the SCoT has the vocation to identify only the main elements of the green structure of the territory, it can ask the PLU to look into finer elements of more local interest in continuity: small streams, sunken lanes, parks and gardens, etc." ${ }^{24}$ It will thus be up to the writers of the PLU to express the TVB at these smaller scales.

\subsubsection{The SCoT, a pertinent scale for a useful awareness tool}

First of all, the environmental assessment procedure imposed when a SCOT is developed provides an opportunity to introduce the set of climate problems relating to the territory. This assessment should, however, be made upstream of the plan so as to allow true reflection on the objectives. If it takes place too late, it will only serve to "justify the bias of the development (chosen beforehand) rather than making an impartial analysis" (Sename, 2008). It is on the occasion of this assessment that a climatic analysis of the territory could be established, which would make easier the consideration of climate and the UHIs in local development choices.

Next, the Presentation Report ${ }^{25,26,27}$ gives a diagnostic survey of the territory and explains the choices made to establish the Land Use and Sustainable Development Plan (PADD) and the Orientations and Objectives Document (DOO). It describes the links with other documents, such as the PCET and the regional ecological coherence schemes. The presentation report could thus describe the climate zone in which the territory is situated, give data on the local climate, and finally explain the extent to which it is taken into consideration by the choices made in the SCoT. Similarly, reflection on adaptation to climate change could be integrated in the PADD.

The orientations and objectives document (DOO) could make recommendations to take the urban climate into account in urban planning and development practices, such as valorizing plants in the city. In this sense, the SCoT can "define the objectives to be attained concerning the maintaining or creation of green spaces in areas covered by an opening to urbanisation". ${ }^{28}$ Though this provision is simply permissive and not prescriptive, it is nevertheless a step in the right direction.

Admittedly, neither the fine scale required for UHI analysis, nor the objectives of the SCoT enable thermal stress attenuation actions to be precisely defined. On the one hand, measurements at district and even street scale are necessary to analyse the consequences according to the surfaces, whereas the elaboration of a SCoT requires a global, multi-theme approach, at the scale of the inter-municipal territory. Technically, the scale is thus not precise enough to collect suitable data and perform follow-up on the assessment.

But the aim of the SCoT is elsewhere: it consists of implementing a global development strategy and not of determining how each plot of land is to be used. It orients the evolution of the territory without expressing the objectives and recommendations as concrete actions. The document can, for example, note in its project the intention of a territory to bring its developments into closer accordance with the climate. Above all, the integration of the UHI theme in the SCoT, and notably in the PADD, would accelerate the growth of awareness downstream, as the orientations of the SCoT are imposed on urban planning documents covering a smaller territory (PLU, maps of villages) and on development operations. Thus, a precise issue included in the PADD will necessarily be incorporated in these various documents.

\footnotetext{
24 DIREN of Brittany on the territory of the SCoT of Concarneau.

25 "The presentation report (...) describes and assesses the notable incidences that the document may have on the environment. It presents the measures envisaged to avoid, reduce and, as far as possible, compensate for negative incidence. It sets out the reasons, notably from the environment protection point of view, why the project was chosen among the development options envisaged. The presentation report contains the information that can reasonably be required considering the knowledge and evaluation methods existing at the time the document is drawn up or revised, given its content and degree of detail and, if appropriate, the existence of other documents or plans relating to all or part of the same geographical area, or environmental assessment procedures planned for a later stage."

${ }^{26}$ Code de l'urbanisme art. L. 121-10.

27 Code de l'urbanisme art. L. 121-11.

28 Code de l'urbanisme 122-1-5 VII.
} 
It would thus be useful for the SCoT to fix objectives for thinking or studies on UHIs and to encourage measures to limit them. The idea would be to use the SCoT to best advantage, as a policy, or even educational document, containing fairly general strategic objectives which, by ceasing to be incantatory, could offer strong encouragement.

\subsubsection{Charters and local Agendas 21, overly broad tools}

Finally, the territorial environment Charters and local Agendas 21 could appear to be interesting tools for considering UHIs, firstly by their spatial scales, which can be fairly diverse, and secondly because these engagements show the interest the elected representatives accord, at least for the eyes of the public, to environmental problems.

But the weakness of these tools, apart from their low statutory value, stems mainly from the field of analysis and reflection being too large, thus preventing the urban warming issue from being targeted satisfactorily. In fact, this tool can tackle an unlimited range of environmental problems. In consequence, the diversity of themes touched upon (water, waste, air, noise, energy, hazards, environmental awareness...) weakens the engagements that could concern urban warming and the resulting provisions are limited to aiming to ensure "good quality of the air and landscape" or "treatment with plants" with no explanation of how or why. It thus seems that the virtues of this type of document, turned towards encouragement and seeking consensus, are also its vices, which are expressed by over-general, largely incantatory objectives that do not enable a technically useful approach to be made to the question of UHIs for the present.

\subsubsection{Integrating the creation of oases of freshness in local plans (PLU)}

The PLU appears, both by its local scale and by its binding statute, to be the most effective tool for taking action against urban warming. The legislative texts have evolved to gradually increase the number of its environmental or climate missions: reflection, followed by recommendations, concerning UHIs is to be included among them.

The preliminary studies for the PLU may include urban climate maps. Such maps allow to determine districts were amenities are needed, like increasing vegetation and green spaces.

In addition, certain PLUs "that are likely to have notable effects on the environment", particularly if they apply to an extensive area, if they authorise works or development that are significant or are situated in a sensitive environment, ${ }^{23}$ must undergo an environmental assessment, which will evaluate the measures taken to prevent or limit "the harmful consequences for the environment of the implementation of the plan". ${ }^{29}$ This assessment may provide an occasion to analyse the local climate parameters (temperatures, precipitation, winds) and their interactions with the ground cover and the shapes of the town (sensitivity of urban fabric to UHIs).

Drawing up a PLU implies making a more detailed analysis of the territory, through the presentation report, which provides a diagnostic survey, an analysis of the initial state of the environment, together with the justifications for the urban project and its incidence on the environment.

Among the documents forming the PLU, the PADD can be the key for integrating issues concerning urban warming (Colombert et al., 2008). The PADD already includes objectives related to natural hazards or the protection of green spaces, so it would be possible to include the question of UHIs by changing the way to approach these existing aims. By referring to data from the preliminary studies, the PADD constitutes the document that allows to know and explain the UHIs phenomenon, to set out objectives and orientations to attenuate them, through the development of public spaces and the rehabilitation of wasteland and vacant land. The PADD could also fix precise quotas for green space surface per head of population.

Zoning is the spatial designation in the PLU of the various land-use on the communal territory: urbanised areas, areas open to urbanisation, areas to be kept as agricultural land, or natural countryside. It can also contribute to the protection of islands of freshness by protecting existing green areas. It would be pertinent to formally include the climate as one of the criteria for defining zones, on the basis of upstream studies. The protection of green spaces could thus be modulated according to the

\footnotetext{
${ }^{29}$ Code de l'urbanisme art. L. 123-2-1.
} 
climatic interest of the zone: simply as part of a natural and forested area ${ }^{30,31}$ or brought under the stricter system of classified wooded area to be preserved. ${ }^{32,33,34}$

Zoning also allows to set up land reserves. This tool would enable available sites within the areas concerned by the UHI problem to be used to increase the cooling capacity of a city. On the sites thus reserved, listed in an appendix to the PLU regulations, no construction would be permitted, as not directly related to the planned green space.

The PLU regulations then state the constraints placed on each zone, which are binding on property developers and individuals. Certain clauses can regulate the management of the green spaces and are consequently able to contain provisions favouring the creation of oases of freshness.

On the subject of including green spaces, the clauses concerning the positions of buildings enable free or interstitial spaces to be preserved. ${ }^{35}$ The rules fixing how far buildings must be set back from the highway allow (or not) for the planting of vegetation at their feet. The rules concerning the setback distance also afford a means of arranging for breaks in the urbanised area to give openings onto enclosed free spaces. Similarly, there are rules fixing the shadowing of neighbouring buildings. A balance can thus be found between cooling by shade and cooling by an oasis of freshness, depending on the characteristics of the space concerned.

The methods to set up and manage green spaces, together with the type of vegetation that is acceptable, can also be regulated. Recommendations may state that the free spaces created should be contiguous with those already existing on neighbouring plots so as to ensure a continuity of building-free spaces with vegetation, that parks should be extended or created, that green roofs should be installed or trees planted around car parks. Finally, it is possible to protect trees, whether they are remarkable or not (obligation to replant if felling is indispensable), to preserve the atmosphere of landscapes and to enhance the value of natural spaces.

The PLU may be completed by schedules of recommendations, and the latter could concern the urban microclimate. So the PLU regulations can provide considerable leverage in favour of the creation of oases of freshness.

\subsection{Treating the question of UHIs at district scale}

It may also be advisable to work on the UHI question on a smaller scale, within the PLU, at the scale of an urban quarter that is particularly dense or is in course of development.

If observations are available, the infra-local scale is appropriate for precise knowledge of the climate characteristics and allows suitable oases of freshness to be planned. The nature, size and location of the necessary works can then be studied specifically. As the installations in eco-districts have shown, it appears useful for the issue of adaptation to urban warming to be included from the design stage.

Deliberations and technical recommendations can be translated in the regulations of the ZAC or housing estate. These rules form the statutory framework that may concern smaller zones or accompany new development operations. They can thus provide the technical recommendations for the creation of islands of freshness that will be applicable over the whole area concerned by the development. These contractual documents complete the statutory provisions contained in the town's urban planning documents.

\footnotetext{
${ }^{30}$ The classification as a Natural and forested area (zone N) confers strong protection on the spaces it covers since, allowing for exceptions, they cannot be built upon. However, it is generally used only for large urban parks or woods. For this reason, some towns use a subcategory of the urban zone (U), the urban green zone (UV) intended for landscaping or recreational purposes, which applies to parks and gardens, stadiums and other little-built-up spaces.

31 Code de l'urbanisme art. R.123-8.

32 These may be hedges or isolated trees; the classification does not depend on the prior existence of a woodland formation. The classified woodland spaces (EBC) indicated in the graphic documents of the regulations come under legislation that subjects them to a specific, very protective system. Any change in land use liable to compromise the conservation, protection or creation of woods, and also any clearing, is forbidden. The cutting and felling of trees, with the exception of special cases, is subject to prior declaration. In addition, this system allows for the transfer free of charge (to the state, the town, the département or a state establishment) of an EBC to be conserved, protected or created, in exchange for compensation in the form of a plot of land for building or an authorization to build on the equivalent of $10 \%$ of the EBC-classified zone not transferred.

33 Code de l'urbanisme art. L. 130-1.

34 Code de l'urbanisme art. L. 130-5.

${ }^{35}$ Articles 6, 7 and 8 of the Paris PLU.
} 
First of all, the ZAC creation file must obligatorily contain an impact assessment, which could envisage ways of limiting UHIs. Similarly, the development concession, drawn up between the municipality and the developer, can lay down instructions on how the zone is to be developed from an environmental point of view. In this way, the handling of UHIs and the creation of oases of freshness can be imposed from the design stage. Provisions for the environment can also be inserted directly into the specifications for the land transfer (CCCT) by way of the schedule of environmental specifications (CPE), or in a manual of recommendations. These documents contain obligations for the developer, who is bound to respect the clauses inserted. These are simple tools, illustrated with examples, in which specific provisions can be included (efforts made to ensure summer comfort, bioclimatic design, coefficients of permeability and green spaces, water management, green roofs and green walls, etc.). The level of detail may go as far as specifying a range of plants suited to the soil and the climate.

As far as a housing estate is concerned, its creation can be accompanied by a set of estate rules if further details are added to the binding town planning regulations. The developer can thus set more restrictive planning rules, taking the question of summer comfort into account.

It should, however, be noted that, although these infra-local tools may be pertinent, their effectiveness remains limited by two factors. On the one hand, they depend on the authorities' degree of awareness of the issues concerning adaptation to urban microclimates. On the other hand, these tools mainly concern the process of opening land to urbanisation and are thus most often used in zones that have not yet been built up, on the outskirts of cities. Conversely, heat islands generally occur in the very dense fabric of city centres. Thus, creating oases of freshness at very local scale, in these new areas, avoids an aggravation of the situation but does not have an effect in places where it is the most needed. Actions on the existing urban fabric, such as urban renewal or renovation, need to be given greater importance or, at least, should not be pushed aside. Actions restricted to certain target areas will remain insufficient if they are not integrated in a more global strategy, such as the considerable increases in the areas of vegetation and water suggested for the Paris area (Masson et al., 2012).

\section{Conclusions}

The integration of the issue of urban warming in French town planning documents is still taking place extremely slowly in spite of the psychological effect of the heat wave of 2003.

The "Grenelle 2" act fixed a mandatory time frame for setting up tools specifically dedicated to the mitigation and adaptation to climate change. ${ }^{36}$ The urgency shown in this legislation will certainly accelerate the response but, on the other hand, a certain precipitation can be feared because of the short time available. The first generation of programmes (SRCAE and PCET) may be adopted rather as emergency measures, without being founded on sufficiently thorough, serious studies. If these tools elaborated at regional or inter-municipal level subsequently appear to be unreliable and their recommendations questionable, there is a risk that their objectives will not be strongly expressed in SCoTs, PLUs and local documents.

It will be necessary to wait for the evaluation, and possible revision, of the SRCAEs, PCETs and SCoTs, planned to take place after 5 or even 6 years, to obtain feedback on how the stated objectives have been put into practice and to improve the content of the measures advocated. This is certainly not a new situation as planning tools for environmental matters have generally followed this process of gradual improvement. Nevertheless, it will be important to pay close attention to how the procedures are linked together, between the PCETs and the land-use planning documents (SCOT and PLU), so as to ensure that recommendations concerning adaptation to urban warming are usefully transcribed, in a timely manner, at local scale. There is no doubt that the work to integrate these themes in town planning documents will require interdisciplinary teams. It seems indispensable to include climatologists specialising in urban microclimates in the town planning teams, as is already done in other countries, e.g. Germany and Japan.

\footnotetext{
36 These are the Regional Climate, Air and Energy Schemes (SRCAE), and the Territorial Climate and Energy Plans (PCET). SRCAE were to be passed within a year of when law $n^{\circ} 2010-788$ of 12 July 2010, which states the national engagement for the environment (Art L. 222-3 of the Code de l'environnement), came into force. A circular from the Ministry of Ecology, Sustainable development, Transport and Housing of 29 July 2011 put the date limit back to the end of 2011. PCETs must be drawn up by 31 December 2012 (Art. L229-26 of the Code de l'environnement).
} 
Finally, more global reflection, including questions of sociology and equity, needs to be undertaken. In fact, the impact of climate change on cities brings out the following paradox: it is the populations living in urban conditions the most favourable for climate change mitigation (density, verticality, limitation of transport) that suffer the strongest effects of the UHI.

Particular attention needs to be paid to the segregation effect that can be generated by the setting up of islands of greenery. The spatial segregation with which eco-districts are reproached, sometimes being called "green ghettos", can also apply here. It is thus important to act equitably in order to attenuate, or avoid creating, additional - microclimatic - inequalities, affecting comfort in summer weather and vulnerability to episodes of prolonged heat waves. The acceptability of urban planning constraints in connection with adaptation to climate change requires an approach incorporating dialogue and the participation of the population.

\section{Acknowledgements}

The authors would like to thank Dr. Valery Masson and Susan Becker for his important role and support in the manuscript translation. Research from GAME/CNRM (Meteo-France, CNRS) were supported by the French National Research Agency (ANR) under grant ANR-09-VILL-0003 and the Scientific Cooperation Foundation STAE in Toulouse in the context of the MUSCADE and ACCLIMAT projects respectively.

\section{References}

Arnfield, A.J., 2003. Two decades of urban climate research: a review of turbulence, exchanges of energy and water, and the urban heat island. International Journal of Climatology 23, 1-26.

Barradas, V.L., 1991. Air temperature and humidity and human comfort index of some city parks of Mexico City. International Journal of Biometeorology 35, 24-28.

Beaulant, A.L., Lemonsu, A., Somot, S., Masson, V., 2012. NATO science for peace and security series C: environmental security. National Security Human Health Implications of Climate Change, 135-145.

Benzerzour, M., Masson, V., Groleau, D., Lemonsu, A., 2011. Simulation of the urban climate variations in connection with the transformations of the city of Nantes since the 17th century. Building and Environment 46, 1545-1557.

Evolution des températures de la métropole lilloise entre 1950-2000. Bigot S., Charabi Y., and Beltrando G. Hommes et Terres du Nord. Revue de l'UFR de Géographie et d'Aménagement, Université Lille 1, Sciences et Technologies, Centre Nationale de la recherche Scientifique, p. 3-14. France. <http://www.univ-lille1.fr/gma/autbigot.htm> Centre Nationale de, 2002.

Boé, J., Terray, L., Habets, F., Martin, E., 2006. A simple statistical-dynamical downscaling scheme based on weather types and conditional resampling. Journal of Geophysical Research 111.

Bowler, D.E., Buyung-Ali, L., Knight, T.M., Pullin, A.S., 2010. Urban greening to cool towns and cities: a systematic review of the empirical evidence. Landscape and Urban Planning 97, 147-155.

Bretin P, Vandentorren S, Zeghnoun A, Ledrans M. Etude des facteurs de décès des personnes âgeées résidant à domicile durant la vague de chaleur d'août 2003. s.l.: Institut de Veille Sanitaire (InVS) Web site. <http://www.invs.sante.fr/publications/ 2004/chaleur2003_170904/rapport_canicule.pdf>, 2005.

Buccolieri, R., Salim, S.M., Leo, L.S., Di Sabatino, S., Chan, A., Ielpo, P., de Gennaro, G., Gromke, C., 2010. Analysis of local scale tree-atmosphere interaction on pollutant concentration in idealized street canyons and application to a real urban junction. Atmospheric Environment 45, 1702-1713.

Ca, V.T., Asaeda, T., Abu, E.M., 1998. Reductions in air conditioning energy caused by a nearby park. Energy and Buildings $29,83-$ 92.

Cantat, O., 2004. L'îlot de chaleur urbain parisien selon les types de temps. Norois, 75-102.

Charabi, Y., Kergomard, C., Bigot, S., Beltrando, G., 2002. Le climat urbain de l'agglomération lilloise: configuration spatiale et variations temporelles de l'ilot de chaleur urbain. Les échelles fines en climatologie. Hommes et terres du Nord 1, 1-5.

Clarke, K.C., Hoppen, S., Gaydos, L., 1997. A self-modifying cellular automaton model of historical urbanization in the San Francisco Bay area. Environment and Planning B: Planning and Design 24, 247-261.

Colombert, M., 2008. Contribution à l'analyse de la prise en compte du climat urbain dans les différents moyens d'intervention sur la ville, Ph.D. Dissertation.

Pierre Crépeaux, official representative for "air, plan, climate and noise" of the Grand Lyon ecology mission in "Le bon Plan Climat du Grand Lyon”, ADEME\&Vous n²6, June 2009.

Cros, B., Durand, P., Prejafon, E., Kattmeïer, C., Perros, P.E., Peuch, V.-H., Ponche, J.-L., Robin, D., Saïd, S., Toupanace, G., Worthan, H., 2004. The ESCOMPTE Program: an overview. Atmospheric Research 69, 241-279.

Ilots de chaleur urbains, puits de fraîcheur. s.l.: Environment Department of the City of Grenoble, 2008. p. 10.

Déqué, M., Jones, R.G., Wild, M., Giorgi, F., Christensen, J.H., Hassell, D.C., Vidale, P.L., Röckel, B., Jacob, D., Kjellström, E., de Castro, M., Kucharski, F., van den Hurk, B., 2005. Global high resolution versus limited-area model scenarios over Europe: results from the PRUDENCE project. Climate Dynamics 25, 653-670.

Déqué, M., Rowell, D., Lüthi, D., Giorgi, F., Christensen, J.H., Rockel, B., Jacob, D., Kjellstrom, E., de Castro, M., van den Hurk, B., 2007. An intercomparison of regional climate models for Europe: assessing uncertainties in model projections. Climate Change. 
Dubuisson, B., Moisselin, J.-M., 2006. Evolution des extrêmes climatiques en France à partir des séries observées. La Houille Blanche 6, 42-47.

Eliasson, I., 1996. Urban nocturnal temperatures, street geometry and land use. Atmospheric Environment 30, 379-392.

Eumorfopoulou, E., Aravantinos, D., 1998. The contribution of a planted roof to the thermal protection of buildings in Greece. Energy and Buildings 27, 20-36.

Eumorfopoulou, E.A., Kontoleon, K.J., 2009. Experimental approach to the contribution of plant-covered walls to the thermal behaviour of building envelopes. Journal of Building and Environment 44 (5), 1024-1038.

European Amica Project (Adaptation and Mitigation, an Integrated Climate policy Approach). Urban community of Grand Lyon. <http://www.ale-lyon.org/le-centre-de-ressources/programmes-suivis-et-acheves/amica.html>.

Evin C., d'Aubert F. 2004. Le drame de la canicule: une gestion déficiente révélatrice d'une crise structurelle, Assemblée Nationale, Paris, pp. $233+575$.

Phénomènes radiatifs et îlot de chaleur urbain dans l'agglomération de Strasbourg, 2009. Ficher, Laurent. s.l.: Revues.org Fédération de revues scientifiques en sciences humaines et sociales (France).

Fujibe, F., 2010. Urban warming in Japanese cities and its relation to climate change monitoring. International Journal of Climatology.

Gaffin, S.R., Rosenzweig, C., Khanbilvardi, R., Parshall, L., Mahani, S., Glickman, H., Goldberg, R., Blake, R., Slosberg, R.B., Hillel, D., 2008. Variations in New York City's urban heat island strength over time and space. Theoretical and Applied Climatology 94, $1-11$.

Grenelle engagement $n^{\circ} 76$, reused in the programme law of 3 August 2009 and in the sustainable city plan.

Hidalgo, J., Pigeon, G., Masson, V., 2008. Urban-breeze circulation during the CAPITOUL experiment: experimental data analysis approach. Meteorology and Atmospheric Physics 102, 223-241.

Hidalgo, J., Masson, V., Pigeon, G., 2008. Urban-breeze circulation during the CAPITOUL experiment: numerical approach. Meteorology and Atmospheric Physics 102, 243-262.

Houes-Jouve S. Rapport final du projet exploratoire de recherche interdisciplinaire "Formes urbaines, modes d'habiter et climat urbain dans le périurbain toulousain". Programme. s.l.: Programme Interdisciplinaire de Recherche Ville et Environnement (PIRVE) 2008-2010, 2010.

Jauregui, E., 1991. Influence of a large urban park on temperature and convective precipitation in a tropical city. Energy and Buildings $15,457-463$.

Jones, P.D., Groisman, P.Y., Coughlan, M., Plummer, N., Wangl, W.C., Karl, T.R., 1990. Assessment of urbanization effects in time series of surface air temperatures over land. Nature 347, 169-172.

Krayenhoff, E.S., Martilli, A., Bass, B., Stull, R.B. 2003. Mesoscale simulation of urban heat mitigation strategies in Toronto, Canada. In: Fifth International Conference on Urban Climate, Lodz, Poland.

Laaidi K., Ung A., Wagner V., Beaudeau P., Pascal M., 2012. Système d'alerte canicule et santé: principes, fondements et évaluation. s.l.: Saint-Maurice: Institut de veille sanitaire, p. 19.

Lafore, J.P., Stein, J., Asencio, N., Ducrocq, P.V., Duron, J., Fischer, C., Hereil, P., Mascart, P., Masson, V., Pinty, J.P., Redelsperger, J.L., Richard, E., Vila-Guerau de Arellano, J., 1998. The Meso-NH atmospheric simulsimulation system. Part I: Adiabatic formulation and control simulation. Annales Geophysics 16, 90-109.

Lambert-Habib, M.L., 2011. VuLiGAM-Vulnerabilité des systèmes Littoraux d’une Grande Agglomeration Méditerranéenne.

Lemonsu, A., Masson, V., 2002. Simulation of a summer urban breeze over Paris. Boundary-Layer Meteorology 104, 463-490.

Lemonsu, A., Grimmond, C.S.B., Masson, V., 2004. Modeling the surface energy balance Marseille: 3D urban boundary layer and thermodynamic fields near the surface. Theoretical and Applied Climatology 74 (2), 1-12.

Lemonsu, A., Kounkou-Arnaud, R., Desplat, J., Salagnac, J.-L., Masson, V., 2012. Evolution of the Parisian urban climate under a global changing climate. Climatic Change.

Lyonnaise, 2010. Agence d'urbanisme pour le développement de l'agglomération. Identification des îlots de chaleur de l'agglomération lyonnaise, vulnérabilité des populations et mesures envisageables de résorption.

Maiheu, B., de Maerschalck, B., Vankerkom, J., Janssen, S., 2010. Local air quality and its interaction with vegetation in the urban environment: a numerical simulation using ENVI-MET. In: 13th Conference on Harmonisation within Atmospheric Dispersion Modelling for Regulatory Purposes, Paris, France.

Martin, E. Etchevers, P., 2005. Impact of climatic change on snow cover and snow hydrology in the French Alps. In: Huber U.M., Bugmann, H.K.M. Reasoner, M.A. (Eds.), Global Change and Mountain Regions (A State of Knowledge Overview), Springer.

Masboungi, A., 2008. Faire la ville durable, Coll. Ateliers projet urbain-DGALN, Le Moniteur, Breda.

Masboungi, A., 2010. La démarche de projet urbain anticipe la ville durable, Special Issue of Urbanisme, vol. 36, pp. 46-48.

Masson, V., Gomes, L., Pigeon, G., Liousse, C., Pont, V., Lagouarde, J.-P., Voogt, J., Salmond, J., Oke, T., Hidalgo, J., Legain, D., Garrouste, O., Lac, C., Connan, O., Briottet, X., Lachérade, S., 2008. The Canopy and Aerosol Particle Interactions in TOulouse Urban Layer (CAPITOUL) experiment. Meteorology and Atmospheric Physics 102, 135-157.

Masson, V., Lion, Y., Peter, A., Pigeon, G., Buyck, J., Brun, E., 2012. "Grand Paris": regional landscape change to adapt city to climate warming. Climatic Change (submitted).

Matzarakis, Andreas, Manuela De Rocco, Najjar, Georges, 2003. Thermal bioclimate in Strasbourg - the 2003 heat wave. Theoretical and Applied Climatology 89, 209-220.

Menut, L., Vautard, R., Flamant, C., Abonnel, C., Beekmann, M., Chazette, P., Flamant, P.H., Gombert, D., Guedalia, D., Kley, D., Lefebvre, M., Lossec, B., Martin, D., Megie, G., Sicard, M., Perros, P., Toupance, G., 2000. Measurement and modeling of atmospheric pollution over the Paris area: the ESQUIF Project. Annales Geophysicae 18, 1467-1481.

Mestayer, P.G. et al, 2005. The urban boundary-layer field campaign in marseille (UBL/CLU-Escompte): set-up and first results. Boundary-Layer Meteorology 114, 315-365.

Mesteyer, P., 2011. The experimental campaign FluxSAP: climatological measurements over a heterogeneous urban area. IAUC Newsletter.

Ministerial circular of 11 May 1994. DIREN Ile de France website, <www.ile-de-france.ecologie.gouv.fr>. Various names are to be found: Environment Charter, Sustainable Development Charter or Sustainable Planning Charter, and Charter for Quality of the Envir. 
Moisselin, J.-M., Schneider, M., Canellas, C., Mestre, O., 2002. Changements Climatiques en France au 20ème siècle. Étude des longues séries de données homogénéisées françaises de précipitations et températures. La Météorologie 38, 45-56.

Najjar, G., Kastendeuch, P.P., Stoll, M.-P., Colin, J.-R., Nerry, F., Ringenbach, N., Bernard, J., De Hatten, A., Luhahe, R., Viville, et D., 2004. Le projet Reclus Télédétection, rayonnement et bilan d'énergie en climatologie urbaine à Strasbourg. La Météorologie 46.

Nakicenovic, N., Alcamo, J., Davis, G., de Vries, B., Fenhann, J., Gaffin, S., Gregory, K., Grübler, A., Jung, T.Y., Kram, T., La Rovere, E.L., Michaelis, L., Mori, S., Morita, T., Pepper, W., Pitcher, H., Price, L., Riahi, K., Roehrl, A., Rogner, H.-H., Sankovski, A., Schlesinger, M., Shukla, P., et al, 2000. Emission scenarios. A special report of Working Group III of the Intergovernmental Panel on Climate Change. Cambridge University Press, Cambridge, UK.

Oke, T.R., 1989. The micrometerology of the urban forest. Philosophical Transactions of the Royal Society of London, Series B: Physical Sciences and Engineering 324, 335-349.

Oke, T.R., 1987. Boundary Layer Climates, second ed. Methuen, p. 435.

Onmura, S., Matsumoto, M., Hokoi, S., 2001. Study on evaporative cooling effect of roof lawn gardens. Energy and Buildings 3 , 653-666.

PACA, Confort d'été en. s.l.: Provence Alpes Côte d'Azur Regional Energy Agency. p. 15.

Core Writing Team Pachauri, R.K., Reisinger, A. (Eds.), 2007. Contribution of Working Groups I, II and III to the Fourth Assessment Report of the Intergovernmental Panel on Climate Change. IPCC, Geneva, Switzerland. p. 104.

Pigeon, G., Lemonsu, A., Long, N., Barrié, J., Masson, P., Urban, V., 2006. Urban thermodynamic island in a coastal city analyzed from an optimized surface network. Boundary-Layer Meteorology 120, 315-351.

Planton, S., Déqué, M., Chauvin, F., Terray, L., 2008. Comptes Rendus Geosciences 340 (9-10), 564-574.

Potchter, O., Cohen, P., Bitan, A., 2006. Climatic behavior of various urban parks during hot and humid summer in the mediterranean city of Tel Aviv, Israel. International Journal of Climatology 26, 1695-1711.

PUCA (urban development, construction and architecture plan) news magazine, Nov-Dec 2009, pp. 10-12.

Quenault, B. 2008-2010. Vulnerabilité et résilience aux changements climatiques en milieu urbain. Rennes: s.n.

Rosenzweig, C., Solecki, W.D., Parshall, L., Chopping, M., Pope, G., Goldberg, R., 2005. Characterizing the urban heat island in current and future climates in New Jersey. Global Environment Change 6, 51-62.

V. Sename. 2008. Regards croisés sur l'évaluation environnementale des documents d'urbanisme. Droit et ville, vol. 66.

Shashua-Bar, L., Hoffman, M.E., 2000. Vegetation as a climatic component in the design of an urban street: an empirical model for predicting the cooling effect of urban green areas with trees. Energy and Buildings 31, 221-235.

Shashua-Bar, L., Pearlmutter, D., Erell, E., 2009. The cooling efficiency of urban landscape strategies in a hot dry climate. Landscape and Urban Planning 92 (3-4), 179-186.

Souch, C.A., Souch, C., 1993. The effect of trees on summertime below canopy urban climates: a case study Bloomington, Indiana. Journal of Arboriculture 19, 303-312.

Spronken-Smith, R.A., Oke, T.R., 1998. The thermal regime of urban parks in two cities with different summer climates. International Journal of Remote Sensing 19, 2085-2104.

Takebayashi, H., Moriyama, M., 2007. Surface heat budget on green roof and high reflection roof for mitigation of urban heat island. Building and Environment 42, 2971-2979.

Thayer, R., Maeda, B., 1985. Measuring street tree impact on solar performance: a five-climate computer modeling study. Journal of Arboriculture 11, 1-12.

Viguié, V., Hallegatte, S., 2012. Trade-offs and synergies in urban climate policies. Nature Climate Change 2, 334-337.

Scenarios for Paris development in the twenty-first century: An exercise on the prospective impact of a carbon tax. Viguié, Hallegatte. Bonn, Germany: s.n., 2011. ICLEI 2nd World Congress on Cities and Adaptation to Climate Change.

Wilby, R.L., 2003. Past and projected trends in London's urban heat island. Weather 58, 251-260. 